\title{
Hubungan Stunting dengan Kerentanan Penyakit pada Anak Usia 1-5 Tahun di Desa Panyirapan Kecamatan Soreang Kabupaten Bandung
}

\author{
Nisa Lathifah Rohmatika, ${ }^{1}$ Buti Azfiani Azhali, ${ }^{2}$ Herry Garna ${ }^{2}$ \\ ${ }^{1}$ Program Studi Pendidikan Dokter, Fakultas Kedokteran, Universitas Islam Bandung, \\ ${ }^{2}$ Departemen Ilmu Kesehatan Anak, Fakultas Kedokteran, Universitas Islam Bandung
}

\begin{abstract}
Abstrak
Stunting adalah kondisi balita yang memiliki panjang atau tinggi badan yang kurang jika dibanding dengan usia. Kondisi ini diukur dengan panjang atau tinggi badan yang memiliki nilai $z$-score <-2SD median standar pertumbuhan anak dari World Health Organization (WHO) MGRS (Multicentre Growth Reference Study). Indonesia termasuk ke dalam negara ketiga dengan prevalensi tertinggi di regional Asia Tenggara tahun 2013 sebanyak 36,40\%. Namun, hasil Riset Kesehatan Dasar (Riskesdas) tahun 2018 menunjukkan prevalensinya menurun menjadi 30,8\%. Salah satu dampak dalam jangka panjang adalah kekebalan tubuh menurun sehingga mudah sakit dan risiko tinggi terjadi penyakit. Hal tersebut mendorong peneliti melakukan penelitian mengenai hubungan stunting dengan kerentanan penyakit pada anak usia 1-5 tahun di Desa Panyirapan Kecamatan Soreang Kabupaten Bandung Provinsi Jawa Barat periode Agustus-November 2019. Teknik pengambilan sampel menggunakan metode purposive sampling, sedangkan pengambilan sampel kontrol diambil sesuai dengan kriteria inklusi dan eksklusi. Penelitian ini dilakukan untuk membedakan tingkat kerentanan penyakit (dilihat dari frekuensi dan durasi sakit) pada anak stunting dengan anak tidak stunting usia 1-5 tahun. Rancangan penelitian ini adalah kualitatif dengan menggunakan metode observasional analitik melalui desain studi kohort (cohort). Hasil penelitian menunjukkan tidak terdapat hubungan bermakna antara stunting dan kerentanan penyakit pada anak usia $1-5$ tahun $(\mathrm{p}=0,600)$ dan memiliki faktor risiko 1,333 kali lebih rentan terkena penyakit dibanding dengan balita yang tidak stunting ( $R R=1,333$; IK 95\%: 0,648-2,744). Simpulan, tidak terdapat hubungan antara stunting dan kerentanan penyakit pada anak usia $1-5$ tahun.
\end{abstract}

Kata kunci: Anak, kerentanan penyakit, stunting, usia 1-5 tahun

\section{The Correlation between Stunting and Disease Vulnerability in Children Aged 1-5 Years in Panyirapan Village, Soreang District, Bandung City}

\begin{abstract}
Stunting is a condition of a toddler who has less length or height when compared to age. This condition is measured by the length or height that has a z-score <-2SD median child growth standard from the World Health Organization (WHO) MGRS (Multicentre Growth Reference Study). Indonesia was included in the third country with the highest prevalence in the Southeast Asian region in 2013 at 36.40\%. However, the results of the Riset Kesehatan Dasar (Riskesdas) in 2018 showed the prevalence decreased to $30.8 \%$. One of the impacts in the long term is decreased immunity so that it is easy to get sick and a high risk of disease. This prompted researcher to conduct research on the relationship between stunting and disease susceptibility at the age of 1-5 years in Panyirapan Village, Soreang District, Bandung City, West Java Province in the period August-November 2019. The sampling technique used a purposive sampling method, while the control sampling was taken in accordance with the criteria inclusion and exclusion. This study was conducted to distinguish the level of disease susceptibility (seen from the frequency and duration of illness) in stunting children with non-stunting children aged 1-5 years. The design of this study was qualitative using analytic observational methods through a cohort study design (cohort). The results showed no significant relationship between stunting and susceptibility to disease in children aged $1-5$ years $(\mathrm{p}=0.600)$ and had a risk factor of 1.333 times more susceptible to disease compared to toddlers who were not stunting $(R R=1.333$; 95\%CI: 0.648-2,744). Conclusion there is no relationship between stunting and disease susceptibility in children aged $1-5$ years.
\end{abstract}

Keywords: Age 1-5 years, child, disease susceptibility, stunting

Korespodensi: Nisa Lathifah Rohmatika. Program Pendidikan Sarjana Kedokteran, Fakultas Kedokteran Universitas Islam Bandung. Jl. Taman Sari Nomor 22, Kota Bandung, Provinsi Jawa Barat. HP: +6281214588744. Email: rnisalathifah@yahoo.com 


\section{Pendahuluan}

Sehat adalah kondisi normal atau suatu keadaan sempurna seseorang, baik kondisi fisik, mental, dan kesejahteraan sosial yang merupakan satu kesatuan dan bukan hanya bebas dari penyakit atau kecacatan. ${ }^{1,2}$ Sebagian orangtua masih ada yang menafsirkan anak sehat hanya dilihat dari fisik. Ciri anak sehat dapat dilihat dari berbagai segi antara lain segi fisik, mental, dan sosial. Dilihat dari segi fisik ditandai dengan badan yang sehat dan pertumbuhan jasmani yang normal. ${ }^{1,2}$ Oleh karena itu, kondisi fisik dalam perkembangan dan pertumbuhan anak merupakan salah satu faktor yang perlu diperhatikan dalam indikator sehat. Salah satunya dengan mencegah atau menurunkan angka stunting.

Stunting merupakan kondisi balita yang memiliki panjang atau tinggi badan yang kurang jika dibanding dengan usia. Kondisi ini diukur dengan panjang atau tinggi badan yang memiliki nilai $z$-score $<-2 \mathrm{SD}$ median standar pertumbuhan anak dari World Health Organization (WHO) MGRS (Multicentre Growth Reference Study). Balita stunting termasuk masalah gizi kronik yang disebabkan oleh banyak faktor seperti kondisi sosial ekonomi, gizi ibu saat hamil, kesakitan pada bayi, dan asupan gizi kurang pada bayi. Balita stunting di masa yang akan datang akan mengalami kesulitan dalam mencapai perkembangan fisik dan kognitif yang optimal. ${ }^{3}$

Hasil riset World Health Organization (WHO) menunjukkan bahwa pada tahun 2017, prevalensi stunting di dunia sebanyak 22,2\% atau sekitar 150,8 juta balita, 55\% terdapat di Benua Asia dan 39\% di Benua Afrika. Sekitar 83,6 juta balita stunting di Asia, proporsi terbanyak berasal dari Asia Selatan (58,7\%), yaitu di Afganistan dan proporsi paling sedikit di Asia Tengah $(0,9 \%) \cdot 3,4$

Indonesia termasuk ke dalam negara ketiga dengan prevalensi tertinggi di regional Asia Tenggara dengan prevalensi tahun 2013 sebanyak 36,40\%. ${ }^{5}$ Hasil Riset Kesehatan Dasar (Riskesdas) tahun 2018 menunjukkan prevalensinya menurun menjadi 30,8\%. ${ }^{6}$

Dampak buruk yang dapat ditimbulkan dalam jangka pendek adalah gangguan perkembangan otak, kecerdasan, pertumbuhan fisik, dan metabolisme dalam tubuh. Selain itu, salah satu dampak dalam jangka panjang adalah kekebalan tubuh menurun sehingga akan mudah sakit dan risiko tinggi terjadi penyakit. ${ }^{7}$

Periode tahun 2015 sampai 2019, pembangunan kesehatan difokuskan pada empat program prioritas, yaitu penurunan angka kematian ibu dan bayi, penurunan prevalensi balita pendek (stunting), pengendalian penyakit menular, dan pengendalian penyakit tidak menular. Upaya peningkatan status gizi termasuk penurunan prevalensi balita stunting menjadi salah satu prioritas pembangunan nasional yang tercantum di dalam sasaran pokok Rencana Pembangunan Jangka Menengah tahun 2015-2019.7

Dalam rangka percepatan penurunan angka stunting, pemerintah telah menetapkan 1.000 desa prioritas intervensi stunting yang berada di 100 kabupaten/kota dan 34 provinsi. Ditentukan pula sekitar 10 desa di setiap kabupaten/kota. ${ }^{3}$

Keadaan tersebut mendorong peneliti melakukan penelitian mengenai hubungan stunting dengan kerentanan penyakit pada usia 1-5 tahun di Desa Panyirapan Kecamatan Soreang Kabupaten Bandung Provinsi Jawa Barat. Meskipun desa tersebut tidak termasuk ke dalam 10 desa prioritas intervensi stunting di Kabupaten Bandung, namun desa tersebut memiliki prevalensi stunting yang cukup tinggi dan memenuhi besar sampel minimal.

\section{Metode}

Sampel penelitian ini adalah anak stunting dan tidak stunting usia 1-5 tahun yang datang ke salah satu dari 16 Posyandu pada bulan Agustus sampai November 2019 di Desa Panyirapan Kabupaten Bandung Provinsi Jawa Barat dan telah memenuhi kriteria inklusi dan tidak termasuk kriteria eksklusi. Berdasar rumus uji hipotesis untuk relative risk (RR) pada studi kohort (cohort) atau analitik komparatif kategorik tidak berpasangan didapat besar sampel minimal untuk setiap kelompok adalah 29, dengan demikian jumlah sampel yang dibutuhkan untuk perbandingan dua kelompok adalah 58 ditambah 10\% dengan drop out menjadi 64.

Teknik pengambilan sampel menggunakan metode purposive sampling, sedangkan pengambilan sampel kontrol diambil sesuai dengan kriteria inklusi dan eksklusi. Penelitian ini dilakukan untuk membedakan tingkat kerentanan penyakit pada anak stunting usia 1-5 tahun dengan anak tidak stunting usia 1-5 tahun. Rancangan penelitian ini adalah kualitatif dengan metode observasional analitik melalui desain studi kohort.

Variabel yang digunakan dalam penelitian ini adalah balita stunting (variabel bebas) dan kerentanan penyakit yang dilihat berdasar frekuensi dan durasi sakit (variabel terikat). Variabel kontrol yang diambil yaitu status gizi, status sosioekonomi keluarga, dan tingkat pendidikan ibu. Penelitian ini telah dinyatakan lulus etik dan disetujui oleh Komisi Etik Penelitian Kesehatan Fakultas Kedokteran Universitas Islam Bandung dengan Nomor: 085/Komite Etik.FK/ IV/2019.

\section{Hasil}

Karakteristik anak yang dinilai pada penelitian ini adalah usia, jenis kelamin, penyakit infeksi, status sosioekonomi keluarga, dan tingkat pendidikan ibu. Distribusi karakteristik anak usia 1-5 tahun ini dapat dilihat pada Tabel 4.1.

Berdasar Tabel 2 dapat diketahui terdapat 1 balita stunting dan 3 balita tidak stunting yang mengalami diare. Terdapat 14 balita stunting dan 16 balita tidak stunting yang didiagnosis ISPA. Terdapat 4 balita stunting dan 1 balita tidak stunting yang didiagnosis penyakit lainnya.

Frekuensi sakit diare pada balita stunting sebanyak 1 kali dan pada balita tidak stunting sebanyak 4 kali. Frekuensi sakit ISPA pada balita stunting sebanyak 21 kali dan balita tidak stunting sebanyak 18 kali. Frekuensi penyakit lain dapat dilihat pada Tabel 3 . 
Tabel 1 Karakteristik Anak Stunting dan Tidak Stunting Usia 1-5 Tahun

\begin{tabular}{ccc}
\hline Karakteristik & Stunting & $\begin{array}{c}\text { Tidak } \\
\text { Stunting } \\
\end{array}$ \\
& $(\mathbf{n}=\mathbf{3 4})$ & $(\mathbf{n}=\mathbf{3 4})$ \\
\hline
\end{tabular}

\section{Usia (tahun)}

1

2

3

4

5

Jenis kelamin

Laki-laki

Perempuan

Penyakit infeksi

Diare

ISPA

Demam

DBD

Tifoid

Karies dentis

Tidak sakit

Status sosioekonomi

keluarga

Rendah
Sedang
Tinggi

Tingkat pendidikan ibu

$\begin{array}{lcc}\text { Dasar } & 25 & 25 \\ \text { Menengah } & 7 & 9 \\ \text { Tinggi } & 2 & 0\end{array}$

Keterangan: demam = demam yang tidak diketahui sebab

Tabel 2 Jenis Penyakit pada Anak Stunting dan Tidak Stunting Usia 1-5 Tahun

\begin{tabular}{lcc}
\hline \multicolumn{1}{c}{$\begin{array}{c}\text { Jenis } \\
\text { Penyakit }\end{array}$} & $\begin{array}{c}\text { Stunting } \\
(\mathbf{n}=\mathbf{1 9})\end{array}$ & $\begin{array}{c}\text { Tidak Stunting } \\
(\mathbf{n}=\mathbf{2 0})\end{array}$ \\
\hline Diare & $\mathbf{1}$ & 3 \\
ISPA & 14 & 16 \\
Demam & 1 & 1 \\
DBD & 1 & 0 \\
Tifoid & 1 & 0 \\
Karies dentis & 1 & 0 \\
\hline
\end{tabular}

Tabel 3 Frekuensi Sakit pada Anak Stunting dan Tidak Stunting Usia 1-5 Tahun

\begin{tabular}{lcccc}
\hline \multirow{2}{*}{$\begin{array}{c}\text { Frekuensi } \\
\text { Sakit }\end{array}$} & \multicolumn{2}{c}{ Stunting } & \multicolumn{2}{c}{ Tidak Stunting } \\
Jumlah & $\mathrm{x}$ & Jumlah & $\mathrm{x}$ \\
\hline Diare & 1 & 1,00 & 4 & 1,33 \\
ISPA & 21 & 1,50 & 18 & 1,13 \\
Demam & 1 & 1,00 & 1 & 1,00 \\
DBD & 2 & 2,00 & 0 & 0,00 \\
Tifoid & 1 & 1,00 & 0 & 0,00 \\
Krisis dentis & 2 & 2,00 & 0 & 0,00 \\
\hline
\end{tabular}

Durasi sakit diare pada balita stunting selama 3 hari dan pada balita tidak stunting selama 11 hari. Durasi sakit ISPA pada balita stunting selama 96 hari dan balita tidak stunting selama 72 hari. Durasi penyakit lain dapat dilihat pada Tabel 4.

Tabel 4 Durasi Sakit pada Anak Stunting dan Tidak Stunting Usia 1-5 Tahun

\begin{tabular}{|c|c|c|c|c|}
\hline \multirow{2}{*}{$\begin{array}{l}\text { Durasi Sakit } \\
\text { (Jumlah Hari) }\end{array}$} & \multicolumn{2}{|c|}{ Stunting } & \multicolumn{2}{|c|}{ Tidak Stunting } \\
\hline & Jumlah & $\mathrm{x}$ & Jumlah & $\mathrm{x}$ \\
\hline Diare & 3 & 3,00 & 11 & 3,67 \\
\hline ISPA & 96 & 6,86 & 72 & 4,50 \\
\hline Demam & 3 & 4,75 & 3 & 3,00 \\
\hline DBD & 6 & 0,00 & o & 0,00 \\
\hline Tifoid & 7 & 0,00 & o & 0,00 \\
\hline Dental caries & 6 & 0,00 & o & 0,00 \\
\hline
\end{tabular}

Kerentanan penyakit pada anak usia 1-5 tahun berdasar frekuensi dan durasi sakit dapat dilihat pada Tabel 5 dengan hasil median frekuensi sakit, yaitu 1,00 dan median durasi sakit 5,00. Median inilah yang digunakan sebagai patokan frekuensi dan durasi sakit dalam kerentanan penyakit.

Berdasar uji analisis chi-square maka didapat hasil secara statistik dalam Tabel 6. Parameter kekuatan hubungan yang digunakan adalah RR, yaitu sebesar 1,333 dengan IK 95\%:0,648-2,744.

Dengan demikian, secara statistik tidak terdapat hubungan bermakna (signifikan) antara stunting dan kerentanan penyakit pada anak usia 1-5 tahun $(\mathrm{p}=0,600)$. Namun, pada balita stunting mempunyai faktor risiko 1,333 kali rentan terkena penyakit dibanding dengan balita yang tidak stunting meskipun secara statistik tidak signifikan.

Tabel 5 Kerentanan Penyakit pada Anak Stunting dan Tidak Stunting Usia 1-5 Tahun berdasar Frekuensi dan Durasi Sakit

\begin{tabular}{lcccccccc}
\hline \multirow{2}{*}{ Frekuensi dan Durasi Sakit } & \multicolumn{4}{c}{ Subjek Penelitian } & \multicolumn{2}{c}{ Skewness } & \multicolumn{2}{c}{ Kurtosis } \\
\cline { 2 - 5 } & Mean & Median & SD & Min. & \multicolumn{2}{c}{ Maks. } & \\
\hline Frekuensi sakit & 1,46 & 1,00 & 0,56 & 1,00 & 3,00 & 0,71 \\
Durasi sakit & 5,91 & 5,00 & 3,53 & 1,00 & 18,00 & 1,59 & 3,14 \\
\hline
\end{tabular}


Tabel 6 Hubungan Stunting dengan Kerentanan Penyakit pada Anak Usia 1-5 Tahun

\begin{tabular}{lcccc}
\hline & $\begin{array}{c}\text { Rentan } \\
\text { Sakit }\end{array}$ & $\begin{array}{c}\text { Tidak } \\
\text { Rentan } \\
\text { Sakit }\end{array}$ & Nilai p & $\begin{array}{c}\text { RR } \\
\text { (IK 95\%) }\end{array}$ \\
\cline { 2 - 3 } & $\mathbf{n = 2 1}$ & $\mathbf{n = 4 7}$ & & \\
\hline Stunting & 12 & 22 & & 1,333 \\
Tidak stunting & 9 & 25 & 0,600 & $\begin{array}{c}(0,648- \\
2,744)\end{array}$ \\
\hline
\end{tabular}

\section{Pembahasan}

Stunting adalah kondisi status gizi balita yang didasarkan pada indeks panjang atau tinggi badan kurang jika dibanding dengan usia. Balita stunting menggambarkan masalah gizi kronik yang dipengaruhi oleh kondisi ibu/calon ibu, masa janin, dan masa balita termasuk penyakit yang diderita. ${ }^{3,6}$ Balita stunting termasuk masalah gizi kronik yang disebabkan oleh banyak faktor seperti kondisi sosial ekonomi, gizi ibu saat hamil, kesakitan pada bayi, dan asupan gizi kurang pada bayi. Balita stunting di masa yang akan datang akan mengalami kesulitan dalam mencapai perkembangan fisikdankognitifyang optimal. ${ }^{3}$ Dampak buruk yang dapat ditimbulkan dalam jangka pendek adalah gangguan perkembangan otak, kecerdasan, pertumbuhan fisik, dan metabolisme dalam tubuh. Selain itu, salah satu dampak dalam jangka panjang adalah kekebalan tubuh menurun sehingga mudah sakit dan risiko tinggi terjadi penyakit. ${ }^{6}$ Oleh karena itu, secara teori balita stunting akan rentan terkena penyakit, terutama penyakit infeksi.

Hasil penelitian pada Tabel 1 menunjukkan bahwa distribusi usia, jenis kelamin, dan tingkat pendidikan ibu hampir tidak ada perbedaan proporsi yang signifikan. Hal ini dapat disimpulkan bahwa stunting tidak memiliki hubungan dengan usia dan jenis kelamin untuk melihat faktor risiko karena proporsi usia dan jenis kelamin pada balita stunting dengan tidak stunting hampir sama. Hasil penelitian yang dilakukan terhadap 68 subjek penelitian terdiri atas laki-laki dan perempuan 34 orang masing-masing. Tingkat pendidikan ibu bukan merupakan karakteristik secara langsung untuk menjadi faktor risiko stunting karena masih banyak lagi faktor lain yang dapat memengaruhi stunting, utamanya adalah faktor asupan gizi. Namun, ibu yang memiliki tingkat pendidikan lebih tinggi akan lebih sadar dan memperhatikan kepentingan asupan gizi pada anak. Selain itu, ibu dengan pendidikan lebih tinggi akan lebih mudah untuk memproses berbagai informasi sehingga akan berkaitan erat dengan wawasan pengetahuan terkait gizi anak yang akan mencegah stunting. ${ }^{8}$

Dari status sosioekonomi keluarga, berdasar Tabel 1 keluarga dengan status sosioekonomi rendah memiliki angka kejadian stunting yang lebih tinggi dibanding dengan status sosioekonomi keluarga yang sedang dan tinggi. Berdasar penelitian Aramico dkk.,9 semakin tinggi tingkat pendapatan keluarga maka semakin tinggi kemungkinan mendapat asupan gizi yang cukup dan lebih baik sehingga angka kekurangan gizi akan menurun. Tingkat pendapatan keluarga ini dapat dijadikan salah satu indikator tingkat sosioekonomi keluarga.

Dilihat dari penyakit infeksi yang dialami, perbedaan proporsi tidak terlalu signifikan sehingga secara statistik tidak ada hubungan antara stunting dengan kerentanan terhadap penyakit terutama penyakit infeksi. Namun, jika dilihat dari durasi pada Tabel 4 maka dapat dilihat untuk penyakit diare durasi lebih panjang pada balita tidak stunting, sedangkan untuk penyakit ISPA durasi lebih panjang pada anak stunting. Data yang didapat menunjukkan bahwa angka kejadian penyakit diare lebih tinggi pada anak tidak stunting. Hal ini dapat terjadi karena stunting bukan satu-satunya faktor risiko yang dapat menyebabkan penyakit diare. Faktor lain yang dapat menyebabkan diare antara lain praktik higiene. Balita yang mengonsumsi makanan yang kurang bersih akan meningkatkan risiko diare. Di daerah penelitian masih ada beberapa keluarga yang memiliki kesadaran rendah akan kebersihan. Praktik higiene yang buruk menimbulkan risiko munculnya bakteri dan bakteri ini akan masuk ke dalam tubuh melalui makanan yang disajikan secara kurang bersih sehingga berdampak terhadap kesehatan anak, salah satunya diare. Diare ini akan mengakibatkan balita kehilangan cairan dan zat-zat esensial dalam tubuh serta malabsorpsi zat gizi sehingga anak menjadi semakin gagal tumbuh.

Penelitian terkait diare dan stunting sudah banyak dilakukan, seperti Hien dkk. memperoleh hasil tidak ada hubungan signifikan antara diare dan stunting pada balita. Penelitian lain yang dilakukan Dewi dkk. seperti dikutip Desyanti dan Nindya ${ }^{10}$ mendapatkan hasil yang tidak sejalan antara penyakit infeksi, termasuk diare. Namun, penelitian Desyanti dan Nindya $^{10}$ menunjukkan terdapat hubungan antara diare dan stunting, dengan angka kejadiannya lebih tinggi pada balita stunting dibanding dengan balita tidak stunting yang dikaitkan dengan tingkat higiene keluarga. Perlu diketahui bahwa diare dapat menghambat penyerapan nutrisi. Asupan nutrisi yang kurang memadai pada masa awal kehidupan anak terutama usia 1-3 tahun akan berdampak pada pertumbuhan dan perkembangan yang tidak optimal. ${ }^{11}$

Angka kejadian penyakti ISPA lebih tinggi pada balita stunting dibanding dengan balita tidak stunting yang dapat disebabkan oleh penurunan sistem imun balita pada stunting sehingga mudah terserang oleh penyakit infeksi seperti penyakit infeksi saluran penapasan atas (ISPA) yang dapat mengganggu saluran pernapasan. ${ }^{12}$

Oleh karenaitu, meskipun tidak terdapat hubungan, tetapi tetap stunting ini dapat menjadi faktor risiko untuk rentan terkena penyakit yang dapat dilihat dari $R R=1,333 \quad(R R>1$ maka sebagai faktor risiko) pada Tabel 6. Hal ini dapat terjadi karena terdapat bias dalam penelitian, seperti orangtua yang tidak melaporkan atau membawa anaknya ke tenaga medis maupun tenaga kesehatan untuk berobat sehingga data balita stunting yang mengalami penyakit infeksi tidak tercatat dengan baik. Dilihat dari hasil wawancara pun masih banyak orangtua yang memilih melakukan pengobatan secara tradisional menggunakan tanaman yang telah menjadi resep turun temurun keluarga atau lebih memilih membeli obat secara langsung dari 
apotek tanpa resep dari dokter.

\section{Simpulan}

Hasil penelitian ini menunjukkan tidak terdapat hubungan antara stunting dan kerentanan penyakit pada anak usia $1-5$ tahun. Namun, pada balita stunting memiliki kemungkinan faktor risiko 1,333 kali lebih rentan terkena penyakit dibanding dengan balita yang tidak stunting.

\section{Ucapan Terima kasih}

Ucapan terima kasih penulis tujukan kepada Kepala Desa Panyirapan yang telah memberikan izin untuk melakukan penelitian di Desa Panyirapan. Selanjutnya, terima kasih untuk Bidan dan Kader 16 Posyandu di Desa Panyirapan, serta semua pihak yang telah berkontribusi dalam penelitian ini.

\section{Daftar Pustaka}

1. World Health Organization. Constitution of the World Health Organization. World Health Assembly. Basic Doc. 2006 September 2005; Supplement:1-2.

2. World Health Organization. Basic documents, Edisi ke-48. 2014 [diunduh 27 Januari 2019]. Tersedia dari: http://apps.who.int/gb/bd/ $\mathrm{PDF} /$ bd48/basic-documents-48th-edition-en. pdf\#page $=1$ ).

3. Pusat Data dan Informasi, Kementerian Kesehatan RI. Situasi balita pendek (stunting) di Indonesia. Dalam: Sakti ES, penyunting. Buletin jendela data dan informasi kesehatan. Edisi ke-1. Vol. 1. Jakarta: Pusat Data dan Informasi; 2018. hlm. 56 .

4. World Health Organization. Prevalence of stunting, height for age (\% of children under 5 ) by country (serial online). Index Mundi. 2018 [diunduh 27 Januari 2019]. Tersedia dari: https://www.indexmundi.com/facts/indicators/ sh.sta.stnt.zs.

5. World Health Organization. Indonesia Prevalence of stunting, height for age (\% of children under 5) (serial online). 2018 [diunduh 27 Januari 2019]. Tersedia dari: https://www. indexmundi.com/facts/indonesia/indicator/ SH.STA.STNT.ZS.

6. Kementerian Kesehatan Republik Indonesia. Hasil utama riskesdas 2018. Jakarta: Badan Penelitian dan Pengembangan Kesehatan. Kementerian Kesehatan RI; 2018.

7. Kementerian Kesehatan RI. Situasi balita pendek. Jakarta Selatan: Infodatin Kementerian Kesehatan RI; 2016.

8. Adriani M, Wirjatmadi B. Gizi dan kesehatan balita. Jakarta: Kencana Prenads Media Group; 2014.

9. Aramico B, Sudargo T, Susilo J. Hubungan sosial ekonomi, pola asuh, pola makan dengan stunting pada siswa sekolah dasar di Kecamatan Lut Tawar, Kabupaten Aceh Tengah. Gizi Dietetik Indones. 2013;1(3):121-30.

10. Desyanti C, Nindya TS. Hubungan riwayat penyakit diare dan praktik higiene dengan kejadian stunting pada balita usia 24-59 bulan di wilayah kerja Puskesmas Simolawang, Surabaya. Amerta Nutri. 2017;1(3):243-51.

11. Ulfah E, Rahayuningsih SE, Herman H, Susiarno H, Gurnida DA, Gamayani U, dkk. Asuhan nutrisi dan stimulasi dengan status pertumbuhan dan perkembangan balita usia $12-36$ bulan. GMHC. 2018;6(1):12-20.

12. Solin AR, Hasanah O, Nurchayati S. Hubungan kejadian penyakit infeksi terhadap kejadian stunting pada balita 1-4 tahun. JOM FKp. 2019;6(1):65-71. 


\title{
Hubungan Riwayat Bayi Berat Lahir Rendah dan Jumlah Anak dalam Keluarga dengan Kejadian Stunting Usia 12-59 Bulan di Desa Panyirapan Kabupaten Bandung
}

\author{
Annisa Kusumawardhani, ${ }^{1}$ Waya Nurruhyuliawati, ${ }^{2}$ Herry Garna ${ }^{3}$ \\ ${ }^{1}$ Prodi Pendidikan Dokter, Fakultas Kedokteran, Universitas Islam Bandung, \\ ${ }^{2}$ Departemen Saraf, Fakultas Kedokteran, Universitas Islam Bandung, \\ ${ }^{3}$ Departemen Anak, Fakultas Kedokteran, Universitas Islam Bandung
}

\begin{abstract}
Abstrak
Stunting merupakan permasalahan global yang sedang marak belakangan ini. Hal ini mengindikasikan terdapat berbagai faktor yang dapat menyebabkan stunting. Berat badan lahir rendah merupakan faktor prenatal yang mungkin berhubungan dengan pertumbuhan anak di kemudian hari. Faktor sosial-ekonomi seperti jumlah anak dalam keluarga juga dapat memengaruhi pertumbuhan anak. Tujuan penelitian ini adalah menganalisis hubungan riwayat berat badan lahir rendah dan jumlah anak dalam keluarga dengan kejadian stunting di Desa Panyirapan Kabupaten Bandung periode Maret-Agustus 2019. Subjek penelitian adalah anak usia 12-59 bulan. Penelitian menggunakan rancangan kualitatif metode analitik komparatif dengan pendekatan case control. Uji statistik menggunakan uji chi-square dan Eksak Fisher. Jumlah responden pada penelitian ini adalah 49 anak stunting dan 43 anak tidak stunting. Anak stunting dengan riwayat berat badan lahir rendah sebanyak 5 anak (10\%) dan tidak terdapat hubungan bermakna ( $\mathrm{p}=0,209)$. Anak stunting dengan jumlah anak $>2$ sebanyak 17 anak (35\%) dan terdapat hubungan bermakna ( $\mathrm{p}=0,008 ; \mathrm{OR}=5.18$ ). Simpulan, tidak terdapat hubungan antara berat badan lahir rendah dan kejadian stunting, tetapi terdapat hubungan jumlah anak dalam keluarga dengan kejadian stunting anak usia 12-59 bulan di Desa Panyirapan Kabupaten Bandung.
\end{abstract}

Kata kunci: Bayi berat lahir rendah, jumlah anak, stunting, usia 12-59 bulan

\section{The Relationship between Low Birth Weight and Number of Children with Stunting in Children Aged 12-59 Months in Panyirapan Village, Bandung Regency}

\begin{abstract}
Stunting is a global problem that become a trending these days. This indicates there are factors that can cause stunting. Low birth weight is a prenatal factor that may relate with children development in the future. Social-economic factor such as number of children may also affect the growth of children. The purpose of this study was to analyze the relationship between low birth weight and number of children with stunting in Panyirapan Village, Bandung Regency in March-August 2019. Subjects were children aged 12-59 months. This study used qualitative comparative method using case control. Statistical test using chi-square and Fisher's exact test. Total sample for this study were 49 stunting children and 43 non-stunting children. Stunting children with low birth weight history were 5 children (10\%), and after being tested there was no significant relationship (p-score=0.209). Stunting children with number of children >2 were 17 children (35\%), and after being tested there was significant relationship ( $\mathrm{p}$-score=0.008; $\mathrm{OR}=5.18$ ). In conclusion, there is no relationship between low birth weight and stunting, but there is a relationship between number of children and stunting in children aged 12-59 months in Panyirapan Village, Bandung Regency.
\end{abstract}

Keywords: Aged 12-59 months, low birth weight, number of children, stunting 


\section{Pendahuluan}

Kejadian stunting merupakan permasalahan global yang sedang marak akhir-akhir ini. Berdasar atas data yang telah dilaporkan ke Unicef, tahun 2017 sekitar 151 juta anak balita didiagnosis sangat pendek. Menurut hasil Riset Kesehatan Dasar (Riskesdas) Indonesia tahun 2018, prevalensi balita pendek sebesar 11,5\% dan balita sangat pendek sebesar 19,3\% dengan provinsi kejadian stunting tertinggi di Nusa Tenggara Timur dengan angka kejadian mencapai $42,6 \% .^{1}$ Menurut Profil Kesehatan Jawa Barat tahun 2016 kejadian stunting terdata sebanyak 35,3\% dengan prevalensi di Kabupaten Bandung Barat sebanyak 7,84\%. ${ }^{2}$

Stunting atau perawakan pendek adalah keadaan gangguan proses pertumbuhan anak yang disebabkan oleh asupan nutrisi yang kurang atau infeksi berulang. ${ }^{3}$ Seorang balita dinyatakan pendek apabila hasil pengukuran tinggi badan per usia (TB/U) kurang dari -2SD dan dinyatakan sangat pendek apabila kurang dari -3 SD. Terdapat faktor risiko utama yang dapat menyebabkan kejadian stunting, yaitu kemiskinan, sosial dan budaya, peningkatan paparan terhadap penyakit infeksi, kerawanan pangan, serta akses masyarakat ke tempat pelayanan kesehatan. ${ }^{4}$ Salah satu faktor lain yang menyebabkannya adalah bayi berat lahir rendah (BBLR). Bayi berat lahir rendah (BBLR) merupakan keadaan bayi lahir dengan berat kurang dari 2.500 gram. ${ }^{4}$ Berat badan lahir rendah merupakan indikator status kesehatan masyarakat karena mempunyai korelasi dengan angka morbiditas, mortilitas, dan kejadian gizi kurang di kemudian hari. ${ }^{5}$ Berdasar atas penelitian Arnisam ${ }^{6}$ menunjukkan bahwa seseorang dengan riwayat BBLR memiliki risiko 3,34 kali lebih besar untuk mengalami status gizi kurang.

Selain riwayat BBLR, faktor sosioekonomi dan budaya juga menjadi penyebab stunting. Status gizi balita berkaitan erat dengan kondisi sosioekonomi dan budaya, antara lain pendidikan orangtua, pekerjaan orangtua, jumlah anak dalam keluarga yang menjadi tanggungan, pola asuh ibu, serta kondisi ekonomi orangtua. ${ }^{7}$ Berdasar atas buku Pendekatan Keluarga dalam Pencapaian Prioritas Pembangunan Kesehatan tahun 2017, untuk menandakan suatu keluarga itu sehat atau tidak digunakan sejumlah indikator. Salah satu indikator, yaitu keluarga mengikuti program Keluarga Berencana (KB).

Berdasar atas latar belakang tersebut di atas, peneliti bermaksud menganalisis hubungan riwayat bayi berat lahir rendah (BBLR) dan jumlah anak dalam keluarga dengan kejadian stunting di Desa Panyirapan Kabupaten Bandung.

\section{Metode}

Penelitian menggunakan rancangan kualitatif metode analitik komparatif dengan pendekatan case control. Populasi target pada penelitian ini adalah anak stunting dan normal usia (12-59 bulan) yang datang ke Posyandu di Desa Panyirapan Kabupaten Bandung Provinsi Jawa Barat periode Maret-Agustus 2019.

Subjek penelitian berjumlah 92, yaitu 49 anak stunting dan 43 anak tidak stunting. Teknik pemilihan sampel dalam penelitian ini adalah total sampling. Semua sampel yang datang dan memenuhi kriteria inklusi dan eksklusi dimasukkan ke dalam penelitian. Kriteria inklusi kasus adalah anak usia 12-59 bulan, tinggal di wilayah penelitian, dan termasuk kriteria stunting. Kriteria inklusi kontrol adalah anak usia 12-59 bulan, tinggal di wilayah penelitian, dan tidak termasuk kriteria stunting. Kriteria eksklusi anak yang memiliki kelainan kromosom dan anak yang memiliki kelainan deformitas (memengaruhi tinggi).

Jumlah sampel yang diambil pada penelitian ini ditentukan dengan menggunakan rumus analitik komparatif kategorikal tidak berpasangan beda proporsi. Dari perhitungan rumus didapat $n=39$ untuk variabel berat badan lahir rendah dan $n=23$ untuk variabel jumlah anak dalam keluarga.

Variabel penelitian terdiri atas berat badan lahir rendah, jumlah anak dalam keluarga, dan stunting. Berat badan lahir dikategorikan menjadi dua kelompok, yaitu berat badan lahir $<2.500$ gram dan berat badan lahir $\geq 2.500$ gram. Jumlah anak dalam keluarga dikategorikan menjadi dua kelompok, yaitu jumlah anak dalam keluarga $>2$ dan jumlah anak dalam keluarga $\leq 2$.

Pengumpulan data diambil dengan menggunakan pengisian form yang dilakukan oleh orangtua/wali dari subjek penelitian. Data yang sudah terkumpul kemudian diolah secara komputerisasi. Langkah dalam pengolahan data meliputi editing untuk memeriksa data yang diperlukan terhadap kelengkapan dan ketidaksesuaian informasi, kemudian coding dilakukan untuk mengubah data yang akan berguna untuk data entry, kemudian data entry dimasukkan ke dalam program statistical product and service solution (SPSS), dan terakhir adalah cleaning, yaitu pengecekan ulang untuk melihat kesalahan dan ketidaklengkapan yang kemudian dilakukan koreksi. Uji statistik yang digunakan adalah chi-square dan Eksak Fisher.

Penelitian ini mendapatkan kajian etik dari Komite Etik Penelitian Kesehatan Fakultas Kedokteran Universitas Islam Bandung Nomor: 114/Komite Etik. FK/IV/2018.

\section{Hasil}

Berdasar Tabel 1 dari jumlah 92 responden yang menjadi subjek penelitian di Desa Panyirapan, usia yang mendominasi penderita stunting adalah usia $>36$ bulan sebanyak 30 anak (61\%). Jenis kelamin penderita stunting dan tidak stunting hampir sama antara laki-laki dan perempuan. Pendidikan terakhir ibu, status pekerjaan ibu, usia ibu saat hamil, tinggi badan ibu, juga riwayat pemberian ASI eksklusif tidak berbeda antara stunting dan tidak stunting.

Tabel 2 menggambarkan hasil akhir perhitungan analisis bivariat dengan variabel bebas utama adalah BBLR dan jumlah anak dalam keluarga. Variabel yang memiliki hubungan yang bermakna dengan kejadian stunting adalah jumlah anak dalam keluarga $(\mathrm{p}=0,004$; $\mathrm{OR}=5,18 ; \mathrm{IK}=1,58-16,95)$. Nilai odds ratio adalah 5,18 artinya kemungkinan (odds) anak dalam keluarga yang jumlah anak >2 mengalami kejadian stunting 
5,18 kali dibanding dengan anak dalam keluarga yang jumlah anak $\leq 2$.

Tabel 1 Karakteristik Umum Subjek Penelitian berdasar atas Usia, Jenis Kelamin, Pendidikan Terakhir Ibu, Status Pekerjaan Ibu, Usia Ibu Saat Hamil, Tinggi Badan Ibu, dan Riwayat Pemberian ASI Eksklusif $(\mathbf{n}=\mathbf{9 2})$

\begin{tabular}{|c|c|c|c|c|c|}
\hline \multirow[t]{2}{*}{ Karakteristik } & \multicolumn{2}{|c|}{ Stumting } & \multicolumn{2}{|c|}{$\begin{array}{c}\text { Tidak } \\
\text { Stunting }\end{array}$} & \multirow[t]{2}{*}{ Nilai p } \\
\hline & $n=49$ & $\%$ & $n=43$ & $\%$ & \\
\hline \multicolumn{6}{|l|}{ Usia (bulan) } \\
\hline $12-36$ & 19 & 39 & 18 & 42 & \\
\hline $37-48$ & 12 & 24 & 6 & 14 & $0,434^{*}$ \\
\hline $49-59$ & 18 & 37 & 19 & 44 & \\
\hline \multicolumn{6}{|l|}{ Jenis kelamin } \\
\hline Laki-laki & 26 & 53 & 19 & 44 & $0,396^{*}$ \\
\hline Perempuan & 23 & 47 & 24 & 56 & \\
\hline \multicolumn{6}{|l|}{ Pendidikan terakhir ibu } \\
\hline SD & 15 & 31 & 13 & 30 & \\
\hline SMP & 19 & 39 & 17 & 40 & $0,971^{*}$ \\
\hline SMA & 13 & 26 & 12 & 28 & \\
\hline$>$ SMA & 2 & 4 & 1 & 2 & \\
\hline \multicolumn{6}{|l|}{ Status pekerjaan ibu } \\
\hline Bekerja & 15 & 31 & 12 & 28 & $0,776^{*}$ \\
\hline Tidak bekerja & 34 & 69 & 31 & 72 & \\
\hline \multicolumn{6}{|l|}{$\begin{array}{l}\text { Usia ibu saat hamil } \\
\text { (tahun) }\end{array}$} \\
\hline$\leq 20$ & 6 & 12 & 5 & 12 & $0,927^{*}$ \\
\hline$>20$ & 43 & 88 & 38 & 88 & \\
\hline \multicolumn{6}{|l|}{ Tinggi badan ibu $(\mathrm{cm})$} \\
\hline$<150$ & 19 & 39 & 11 & 26 & $0,178^{*}$ \\
\hline$\geq 150$ & 30 & 61 & 32 & 74 & \\
\hline \multicolumn{6}{|l|}{$\begin{array}{l}\text { Riwayat pemberian ASI } \\
\text { eksklusif }\end{array}$} \\
\hline $\mathrm{Ya}$ & 44 & 90 & 43 & 100 & $0,058^{* *}$ \\
\hline Tidak & 5 & 10 & o & o & \\
\hline
\end{tabular}

Keterangan: * $=$ uji chi-square ${ }^{* *}=$ Uji Eksak Fisher

Tabel 2 Hubungan BBLR dan Jumlah Anak dalam Keluarga dengan Stunting

\begin{tabular}{|c|c|c|c|c|}
\hline \multirow{2}{*}{$\begin{array}{c}\text { BBLR dan } \\
\text { Jumlah } \\
\text { Anak dalam } \\
\text { Keluarga }\end{array}$} & Stunting & $\begin{array}{c}\text { Tidak } \\
\text { Stunting }\end{array}$ & \multirow[t]{2}{*}{ Nilai p } & \multirow[t]{2}{*}{$\begin{array}{c}\text { OR } \\
\text { (IK 95\%) }\end{array}$} \\
\hline & $n=49(\%)$ & $n=43(\%)$ & & \\
\hline \multicolumn{5}{|l|}{$\begin{array}{l}\text { Berat badan lahir } \\
\text { (gram) }\end{array}$} \\
\hline$\leq 2500$ & $5(10)$ & $1(2)$ & \multirow[b]{2}{*}{$0,209^{*}$} & \multirow[b]{2}{*}{$\begin{array}{c}4,80 \\
(0,53- \\
42,57)^{*}\end{array}$} \\
\hline$>2500$ & $44(90)$ & $42(98)$ & & \\
\hline \multicolumn{5}{|l|}{$\begin{array}{l}\text { Jumlah anak } \\
\text { dalam keluarga }\end{array}$} \\
\hline $\begin{array}{l}>2 \\
\leq 2\end{array}$ & $\begin{array}{l}17(35) \\
32(65)\end{array}$ & $\begin{array}{c}4(9) \\
39(91)\end{array}$ & $0,004^{*}$ & $\begin{array}{c}5,18 \\
(1,58- \\
16,95)^{*}\end{array}$ \\
\hline
\end{tabular}

Keterangan: * =analisis bivariat

\section{Pembahasan}

Kejadian stunting lebih banyak terjadi pada anak usia $>36$ bulan (61\%). Hal ini sesuai dengan penelitian Hanum dan Khomsan ${ }^{8}$ di Cianjur yang mendapatkan stunting lebih banyak pada usia 48-59 (29,8\%). Hal ini diduga disebabkan oleh semakin tinggi usia anak maka kebutuhan energi juga semakin tinggi.

Pada kelompok responden yang stunting dan tidak stunting distribusi jenis kelamin laki-laki dan perempuan tersebar rata, tidak terdapat hubungan signifikan antara laki-laki dan perempuan dengan stunting. Hal ini sejalan dengan penelitian yang dilakukan oleh Karundeng dkk. ${ }^{9}$ di Puskesmas Kao Kecamatan Kao Kabupaten Halmahera Utara. Hal ini juga sejalan dengan penelitian Lestari $\mathrm{dkk} .{ }^{10} \mathrm{di}$ Kabupaten Asahan. Penelitian ini tidak sejalan dengan penelitian Hanum dan Khomsan ${ }^{8}$ yang menunjukkan bahwa kejadian stunting lebih banyak mengenai anak laki-laki dibanding dengan perempuan.

Tidak terdapat hubungan antara tingkat pendidikan ibu dan kejadian stunting. Hal ini sejalan dengan penelitian Aramico dkk. ${ }^{11} \mathrm{Hal}$ ini tidak sejalan dengan hasil penelitian Putri $^{7}$ karena terdapat hubungan bermakna $(p=0,022)$. Hal ini juga tidak sejalan dengan penelitian Ni'mah dan Muniroh ${ }^{12}$ Kabupaten Bojonegoro. Berdasar literatur, semakin tinggi tingkat pendidikan ibu maka semakin mudah untuk diberikan edukasi mengenai cara pemberian asupan gizi yang benar dan mengimplementasikan pengetahuannya kepada anak. Dengan demikian, pendidikan ibu yang relatif rendah akan menyebabkan anak mengalami stunting di kemudian hari. ${ }^{5}$

Tidak terdapat hubungan antara status pekerjaan ibu dan kejadian stunting. Hal ini sejalan dengan penelitian Ibrahim dan Faramita ${ }^{13}$ di Kota Makassar. Tetapi hal ini tidak sejalan dengan penelitian Putri ${ }^{7}$ di wilayah Puskesmas Nanggalo Padang. Status pekerjaan ibu dapat memengaruhi asupan gizi balita karena ibu yang bekerja biasanya tidak memiliki waktu yang cukup untuk mengasuh dan mengatur pola makan anaknya sehingga dapat menyebabkan gizi anak menjadi kurang. Umumnya ibu yang bekerja memberikan perhatian lebih sedikit kepada anaknya. ${ }^{8}$

Tidak terdapat hubungan antara usia ibu saat hamil dan kejadian stunting. Hal ini sesuai dengan penelitian Rosha dkk. ${ }^{5}$ bahwa tidak terdapat hubungan. Hasil penelitian menunjukkan nilai $\mathrm{p}=0,24(\mathrm{p}>0,05)$ pada Riskesdas tahun 2007 dan $\mathrm{p}=0,23$ pada Riskesdas tahun 2010 artinya tidak terdapat hubungan antara usia ibu saat hamil dan kejadian stunting.

Tidak terdapat hubungan tinggi badan ibu $\geq 150$ $\mathrm{cm}$ dan tinggi badan ibu $<150 \mathrm{~cm}$ dengan kejadian stunting. Hal ini sesuai dengan penelitian Hanum dan Khomsan ${ }^{8}$ tidak terdapat hubungan asupan gizi dan tinggi badan ibu dengan status gizi anak balita $(p=0,562)$. Hal ini juga sejalan dengan penelitian Nugroho $^{14}$ di Kota Bandar Lampung. Hal ini tidak sesuai dengan penelitian di perkotaan oleh Aridiyah dkk. ${ }^{3}$ bahwa terdapat hubungan antara tinggi badan ibu dan kejadian stunting. Bila salah satu atau kedua orangtua pendek karena memiliki kelainan gen kromosom yang membawa sifat pendek mengakibatkan anak menjadi stunting.

Tidak terdapat hubungan yang bermakna antara 
riwayat pemberian ASI eksklusif dan stunting $(p=0,058)$. Hal ini sejalan dengan penelitian yang dilakukan Azmii dan Arini ${ }^{15}$ di Puskesmas Sukmajaya. Tetapi, hal ini tidak sejalan dengan penelitian yang dilakukan Hendra dkk. ${ }^{16}$ di Aceh. Peneliti menemukan bahwa proporsi balita yang mengalami stunting lebih banyak pada anak yang pemberian ASI tidak eksklusif (75\%) daripada anak yang diberikan ASI eksklusif ( $\mathrm{p}=0,002)$. Hal ini juga tidak sejalan dengan penelitian Pangalila dkk. ${ }^{17}$ di Kabupaten Minahasa bahwa terdapat hubungan bermakna. Pemberian ASI yang baik oleh ibu membantu menjaga keseimbangan gizi anak sehingga tercapai pertumbuhan yang normal. ${ }^{3}$

Hasil penelitian menunjukkan tidak terdapat hubungan yang bermakna antara BBLR dan kejadian stunting $(\mathrm{p}=0,209)$. Hal ini sesuai dengan penelitian yang dilakukan Aridiyah dkk. ${ }^{3}$ yang membandingkan faktor-faktor yang memengaruhi kejadian stunting anak balita di wilayah pedesaan dengan wilayah perkotaan. Tetapi, hal ini tidak sejalan dengan penelitian Sherlla dkk. ${ }^{18}$ di Kota Surakarta. Hal ini juga tidak sejalan dengan penelitian Fitri ${ }^{19}$ di Pekanbaru. Hasil penelitian bertentangan dengan teori bahwa berat badan lahir dapat menjadi penentu kuat terhadap pertumbuhan anak di kemudian hari karena umumnya anak dengan riwayat berat badan lahir rendah sulit mengejar pertumbuhan normal saat masa kanakkanak. ${ }^{20}$

Hasil penelitian menunjukkan terdapat hubungan bermakna antara jumlah anak dalam keluarga dan stunting $(\mathrm{p}=0,004)$. Hal ini sejalan dengan penelitian Putri ${ }^{7}$ di Puskesmas Nanggalo Padang bahwa terdapat hubungan. Hal ini juga sejalan dengan penelitian yang dilakukan Zilda dan Sudiarti ${ }^{20}$ di Sumatera pada balita usia 24-59 bulan. Namun, hasil penelitian tidak sejalan dengan penelitian Aridiyah dkk. ${ }^{3}$ di Kabupaten Jember. Hal ini bertentangan dengan teori yang ada. Ketersediaan makanan pada keluarga dengan jumlah anak lebih banyak umumnya lebih sedikit bila dibanding dengan jumlah anak dalam keluarga cukup. Distribusi makanan yang tidak merata terhadap seluruh anggota keluarga dapat menyebabkan anak balita dalam keluarga menderita kurang gizi.7,20

\section{Simpulan}

Berdasar penelitian di atas dapat disimpulkan bahwa tidak terdapat hubungan riwayat bayi berat lahir rendah (BBLR) dengan kejadian stunting, tetapi terdapat hubungan antara jumlah anak dalam keluarga dan kejadian stunting pada anak usia 12-59 bulan di Desa Panyirapan Kabupaten Bandung.

\section{Ucapan Terima kasih}

Ucapan terima kasih kepada Kepala Dinas Kesehatan Kabupaten Bandung, Kepala Puskesmas Soreang, Ibu Nita selaku bidan Desa Panyirapan, Ibu Juju selaku ketua PKK Desa Panyirapan.

\section{Daftar Pustaka}

1. Kementrian Kesehatan RI. Hasil utama Riskesdas 2018. Jakarta: Kemenkes RI; 2018.

2. Dinkes Jawa Barat. Profil Kesehatan Jawa Barat
2016. Bandung: Dinkes Jabar; 2016.

3. Aridiyah FO, Rohmawati N, Ririanty M. Faktorfaktor yang mempengaruhi kejadian stunting pada anak balita di wilayah pedesaan dan perkotaan. J Pustaka Kesehat. 2015;3(1):163-70.

4. Mahayana SAS, Chundrayetti E, Yulistini. Faktor risiko yang berpengaruh terhadap kejadian berat badan lahir rendah di RSUP Dr. Djamil Padang. 2015;4(3):664-73. [diunduh 27 Januari 2019]. Tersedia dari: http://jurnal.fk.unand.ac.id/index. php/jka/article/view/345/300.

5. Rosha BC, Sisca D, Putri K, Yunita I, Putri S. Determinan status gizi pendek anak balita dengan riwayat berat badan lahir rendah (BBLR) di Indonesia (analisis data Riskesdas 2007-2010). J Eko Kesehat. 2013;12(3):195-205.

6. Arnisam. Hubungan berat badan lahir rendah (BBLR) dengan status gizi anak usia 6-24 bulan. Yogyakarta: UGM; 2007. [diunduh 4 Februari 2019]. Tersedia dari: http://etd.repository.ugm. ac.id/ PenelitianDetail\&act=view.

7. Putri RFD. Penelitian faktor-faktor yang berhubungan dengan status gizi anak balita di wilayah kerja Puskesmas Nanggalo Padang. J Kesehat Andalas. 2015;4(1):254-61.

8. Hanum F, Khomsan A. Hubungan asupan gizi dan tinggi badan ibu dengan status gizi anak balita. J Gizi Pangan. 2014;9(1):1-6.

9. Karundeng L, Ismanto A, Kundre R. Hubungan jarak kelahiran dan jumlah anak dengan status gizi balita di Puskesmas Kao Kecamatan Kao Kabupaten Halmahera Utara. J Keperawatan UNSRAT. 2015;3(1):1-9.

10. Lestari W, Rezeki SHI, Siregar DM, Manggabarani S. Faktor yang berhubungan dengan kejadian stunting pada anak sekolah dasar negeri 014610 Sei Renggas Kecamatan Kisaran Barat Kabupaten Asahan. J Dunia Gizi. 2018;1(1):59-64.

11. Aramico B, Sudargo T, Susilo J. Hubungan sosial ekonomi, pola asuh, pola makan dengan stunting pada siswa sekolah dasar di Kecamatan Lut Tawar, Kabupaten Aceh Tengah. J Gizi Diet Indones. 2016;1(3):121-30.

12. Ni'mah C, Muniroh L. Hubungan tingkat pendidikan, tingkat pengetahuan dan pola asuh ibu dengan wasting dan stunting pada balita keluarga miskin. Media Gizi Indones. 2015;10(1):84-90.

13. Ibrahim IA, Faramita R. Hubungan faktor sosial ekonomi keluarga dengan kejadian stunting anak usia 24-59 bulan di wilayah kerja Puskesmas Barombong Kota Makassar tahun 2014. AlShihah. 2015;7(1):63-75.

14. Nugroho A. Determinan growth failure (stunting) pada anak umur $1 \mathrm{~s} / \mathrm{d} 3$ tahun (studi di Kecamatan Tanjungkarang Barat Kota Bandar Lampung). J Kesehatan. 2016;7(3):470-9.

15. Azmii F, Arini FA. Karakteristik ibu, riwayat ASI eksklusif, dan riwayat penyakit infeksi dengan kejadian stunting pada balita usia 12-59 bulan di wilayah kerja Puskesmas Sukmajaya. J Medika Respati. 2018;13(4):17-23.

16. Hendra A, Rahmad A, Miko A. Kajian stunting pada anak balita berdasarkan pola asuh dan pendapat keluarga di Kota Banda Aceh. J Kesmas 
Indones. 2016;8:63-79.

17. Pangalila YV, Punuh MI, Kapantow NH. Hubungan antara riwayat pemberian ASI eksklusif dengan kejadian stunting pada anak batita di Wilayah Kerja Puskesmas Kawangkoan Kabupaten Minahasa. 2019:8. [diunduh 12 Januari 2020]. Tersedia dari: fkm.unsrat.ac.id/wp-content/ uploads/2014/11/Winny-Artikel.pdf.

18. Sherlla F, Lubis M, Cilmiaty $R$, Magna A.
Hubungan beberapa faktor dengan stunting pada balita berat badan lahir rendah. J Kesehatan Kusuma Husada. 2018:13-8.

19. Fitri L. Hubungan bblr dan asi ekslusif dengan kejadian stunting di Puskesmas Lima Puluh Pekanbaru. J Endur. 2018;3(1):131-7.

20. Zilda O, Sudiarti T. Faktor risiko stunting pada balita (24-59 bulan) di Sumatera. J Gizi Pangan. 2013;8(3):175-80. 